\title{
Contained Identities: The Demise of Yapese Clay Pots
}

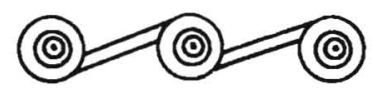

\section{CHRISTOPHE DESCANTES}

EXPLANATIONS FOR THE DISAPPEARANCE of prehistoric Oceanic ceramic traditions have served as topics of much discourse by archaeologists (e.g., Green 1974; Leach 1982; Le Moine 1987; Rainbird 1999). Vanishing at different times, taking on both similar and dissimilar forms and functions, ceramics from Pacific Island societies have served as vital reconstructive data for Oceanic researchers. This paper presents yet another perspective on the cessation of ceramic production in Oceania by investigating the recent process of ceramic pot replacement by metal pots on the island of Yap. With more records on hand, such a study offers a holistic perspective on this dynamic process and contributes insights that need consideration for ceramic change in the more remote Oceanic past.

I apply the following theoretical framework to understand the demise of Yapese ceramic pot production. First, I employ an integrative approach to this analysis, combining archaeological and ethnohistorical evidence to interpret processes of the past. Second, I adopt Dobres and Hoffman's (1999:2) definition of technology as a "pervasive and powerful complex of mutually reinforcing sociomaterial practices structured by self- and group-interests, expressions of agency, identity and affiliation, cultural ways of comprehending and acting on the world, practical and esoteric knowledge, symbolic representations, and skill." Third, I view cross-cultural interaction and resulting culture changes as a process of negotiation whereby the indigenous peoples are active social agents (Torrence and Clarke 2000). Using Thomas' (1997:13) understanding of the term "mutual entanglements," I assume that local cultures are situated and linked within wider cross-cultural histories but not shared nor necessarily shaped by the pervasive colonial culture. This study into the recent past has benefited from informant interviews of people who still remember making and using clay pots-a rarity in Micronesia.

The Caroline Island archipelago of Micronesia spans approximately $3200 \mathrm{~km}$ from Palau (Belau) to Kosrae in the northwest region of the Pacific Ocean between Asia and North America. One of three physiographically distinct island types in the Carolines (see Alkire 1989:12), Yap is a tight cluster of four volcanic-

Christophe Descantes is a postdoctoral fellow at the Archaeological Research Facility, University of California, Berkeley.

Asian Perspectives, Vol, 40, No. 2 (C) 2002 by University of Hawai'i Press. 


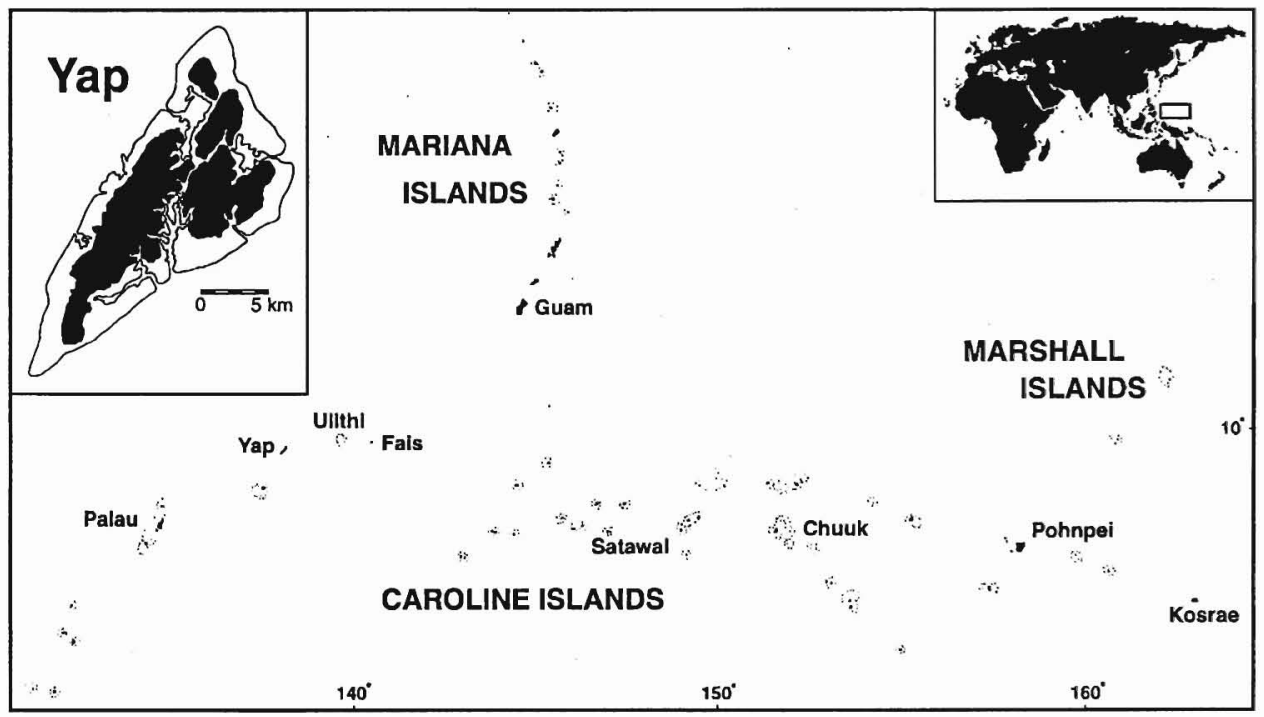

Fig. 1. Micronesia and Yap.

continental islands surrounded by a broad fringing reef in the modern island nation of the Federated States of Micronesia (Fig. 1). Yap's four islands are separated by narrow water passages and form a land mass $31 \mathrm{~km}$ long and $12 \mathrm{~km}$ wide with a combined area of approximately 7925 ha (Hunter-Anderson 1983:3). Situated on the eastern edge of the Andesite Line, unlike its island neighbors to the east, Yap comprises an older and more complex geology of continental rocks and andesitic volcanics that give it clays for pot production.

Unlike most Pacific Islands cases where there was a loss of ceramic technology, pottery production on Yap stopped recently, approximately at the end of the Second World War. This historical end-date gives me access to more avenues of research for synthesizing archaeological findings, ethnohistoric records, and ethnographic works for a contextual understanding of ceramic cessation. I contribute archaeological information and interview data from Yapese elders recollecting the period of pottery use from fieldwork conducted in 1994-1995. Information concerning pottery production was collected from four women in the villages of Gitam, Myub, and Thol, all venues where pots were once made. Matters regarding ceramic use derive from older individuals, predominantly women, born in villages in the northern half of Yap. Ceramic vessels analyzed in this paper derive from archaeological sites in the Yapese villages of Gachpar and Ruu' and are known to originate from Yap (Descantes et al. 2001). From ethnohistoric and ethnographic records, one is able to glimpse, albeit not through a perfectly clear lens, into the past of Yapese society. Despite their biases, ethnohistoric data found in trader, government, and anthropological reports provide invaluable context when clay pots (thib) were already in the process of being replaced by metal pots. The integration of these disparate synchronic and diachronic data allows me to construct the context and identify factors involved in the process of ceramic demise. 


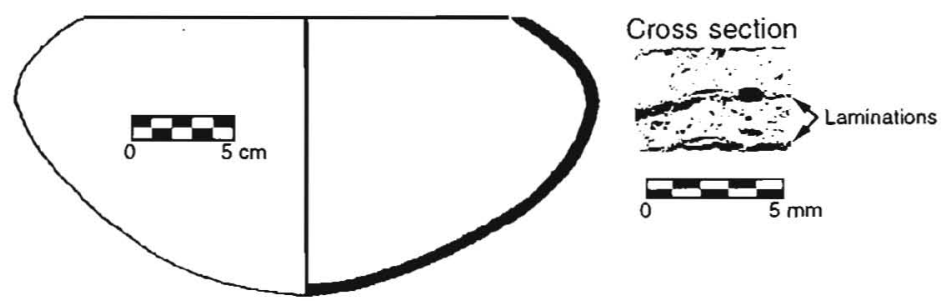

Fig. 2. Yapese Laminated ware pot with cross section (adapted from Intoh and Leach 1985:70). The linear air pockets or laminations appear black because they have been filled with resin in the preparation of the thin section.

A brief description of the development of ceramic technology offered by archaeological investigations gives the necessary precontact context and history of Yapese ceramics to situate technological change within a continuum (see Lightfoot 1995). Ceramic pottery use on Yap was at least a 2000-year-old tradition before it ceased (Intoh and Leach 1985:146). Archaeologists have classified undecorated Yapese potsherds based on their compositional attributes (e.g., see Gifford and Gifford 1959; Intoh and Leach 1985). Similar to other early Micronesian archaeological contexts, such as those in Chuuk (Shutler et al. 1984), Pohnpei (Ayres 1993), Kosrae (Athens 1995), and the Marianas (Graves et al. 1990), Calcareous Sand Tempered pottery (CST) is the oldest artifact type found on Yap. According to Intoh (1988:131), CST pottery lasted 1400 years and was the simplest adaptation to Yapese resources where there was ready access to calcareous sands as opposed to hard terrigenous sands for tempering pottery. Succeeding shorter-lived Yapese wares include Plain, Iron Oxide/Grog Tempered, Quartz-Feldspar, and finally Laminated pottery (Descantes 1998; cf. Intoh 1988).

Laminated pottery (Fig. 2), named after striations visible in cross sections, thought to be a result of strong steam pressure generated by the wetting of the pots just before firing (Intoh 1988:121), emerged at the end of the thirteenth century A.D. (Descantes 1998:201; cf. Intoh 1990:44). The most common ceramic type found on Yap, Laminated pottery has hard walls, no temper, and a uniform incurved bowl shape (Intoh and Leach 1985 :98). From strength tests and Mössbauer spectra analyses indicating that Laminated pots were fired at higher temperatures, Intoh $(1988: 176)$ concludes that Laminated pots were stronger than previous wares. I suggest Laminated pots replaced previous ceramic wares because they were stronger and more suitable for cooking taro, the main staple of the Yapese diet (Descantes 1998:236). Ayres and Haun (1990:219) mention "that the extensive reliance on aroids, particularly Cyrtosperma, in western Micronesian high islands reflects a long process of environmental degradation resulting in reduced yields from other root crops and arboriculture." I propose that Laminated pots replaced previous ceramic types due to intensification in wet-land taro cropping caused by an increasing population. ${ }^{1}$ Yapese people today prefer their taro (e.g., Cyrtosperma chamissonis) to have a very soft consistency; women assert taro needs more cooking than any of the other traditional foodstuffs. Earth ovens (wum) were effective in cooking many Pacific Island starchy vegetables, such as taro, but do not appear to have been used in Yap (Müller 1917:68), ${ }^{2}$ except on 


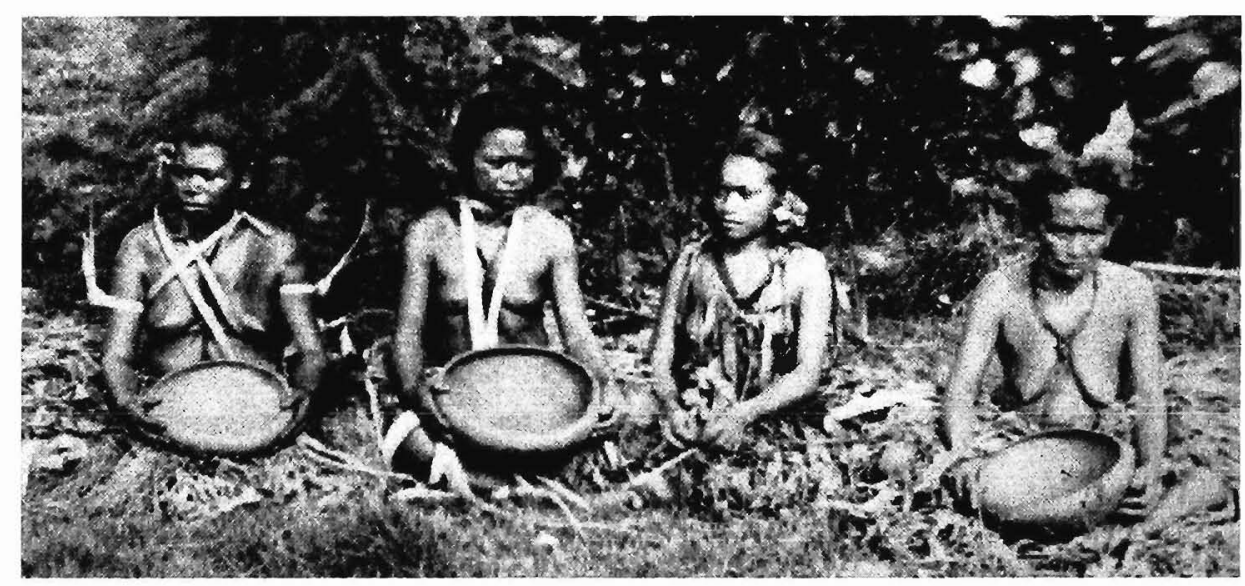

Fig. 3. Yapese women with clay pots in 1934 photographed by Paul $\mathrm{H}$. Clyde entitled "The Matrons of Yap" (1935:66). A woman slightly out of focus in the original is not included.

occasion by non-Yapese people (e.g., Outer Islanders) residing on Yap. At the risk of blurring food distinctions of diverse household members, earth ovens, which were better suited for communal cooking, were possibly not an option for the Yapese because of the labor intensive logistics necessary in distinguishing food.

Pottery manufacture articulated Yapese social identities (Fig. 3). Organized in household industries, certain skilled low-caste (pimilingay) women labored intensively to make pots for themselves and their high-caste (pilung) masters. ${ }^{3}$ Pot making was a service that women performed in exchange for living on and using the land that belonged to a particular high-caste household or what the Yapese refer to as a suon (de Beauclair 1968:46; Labby 1976:86). Other duties low-caste villagers performed for their suon include burying the dead, fencing, roof thatching, weaving, and yard cleaning (Lingenfelter 1975:156-159). A potter might be requested once or twice a year to make pots for their suon. Some potters might be more relied upon than others if they had superior skills, in which case their suon would request additional pots on the behalf of others. The village of Gitam was renown for better-quality pots. In general, a low-caste potter who did not obey the requests of their suon risked being chased from the land. Low-caste people also received gifts for their services. One elderly informant told me that her grandmother received baskets of goods, such as fish and fresh coconuts, for her pot-making services.

More information on ceramic production and its importance are manifested in a myth collected as early as the late nineteenth century. According to the myth, the "God of Thunder" taught a woman in the low-caste village of Dinay how to make fire, form clay vessels, and cook with pots (Christian 1967:320-321; Müller 1918:606-607; Gifford and Gifford 1959:180). Oral tradition has it that the god also relayed spells to the potter that could make pots either strong or weak depending on what the person wanting the vessel gave in exchange for it. The myth indicates that pottery making was a valuable skill; potters controlled the quality of their pots and deserved suitable compensation for their services. 
Yapese pottery manufacture has been described before so I only briefly review it here (de Beauclair 1960:65-66; Gifford and Gifford 1959:180-181; Intoh and Leach $1985: 127-145)$. According to informants, pottery making was labor intensive and included restrictions. Informants told de Beauclair (1960:65) that a pot maker abstained from sexual intercourse and would take a bath and rub her body with shredded coconut meat before getting clay, while informants relayed to Intoh (1988:124) that only females whom had had their first menstrual cycle made pots. According to Gifford and Gifford's (1959:181) Gitam informants, pots were made in the high-elevation grasslands (teyid) by women. After clay procurement, a substantial amount of time was spent removing natural nonplastic inclusions from the montmorillonite-rich clay. Cleaning the large amount of clay needed to make a big pot could take the entire day. Pots were made in sets of five. Using the hand-building technique of coiling, women made pots in sheds isolated from the rest of the village. Untempered pots dried for months in these sheds before being fired upside down in open-air hearths, and contrary to other potting traditions in the world, pots were wetted before firing (Intoh 1988:121). Temperatures in the oxidizing atmosphere of the coconut frond and husk hearths ranged from 700 to $800{ }^{\circ} \mathrm{C}$ (Intoh 1988:72, 102). Potters were restricted from eating fish before firing pots due to the belief it would prevent them from cracking (Gifford and Gifford 1959:181). Pots with any trace of skin or hair, accidentally deposited by a low-caste individual after the firing process, were rejected and their makers punished severely by high-caste masters (de Beauclair 1960:65-66). According to a Gitam potter, one of the few remaining women who remember how to make traditional pots, 80 percent of the completed pots would turn out successfully, the rest exhibiting cracks. Pots could last four or five years if properly cared for.

Considered implements, clay pots did not communicate messages in their aesthetic form (Fig. 4). Clay pots were tools valued for their durability and cooking abilities. Unlike other Oceanic peoples in prehistory who stopped using clay pots (see Leach 1982), the Yapese did not rely on earth ovens to cook their tubers.

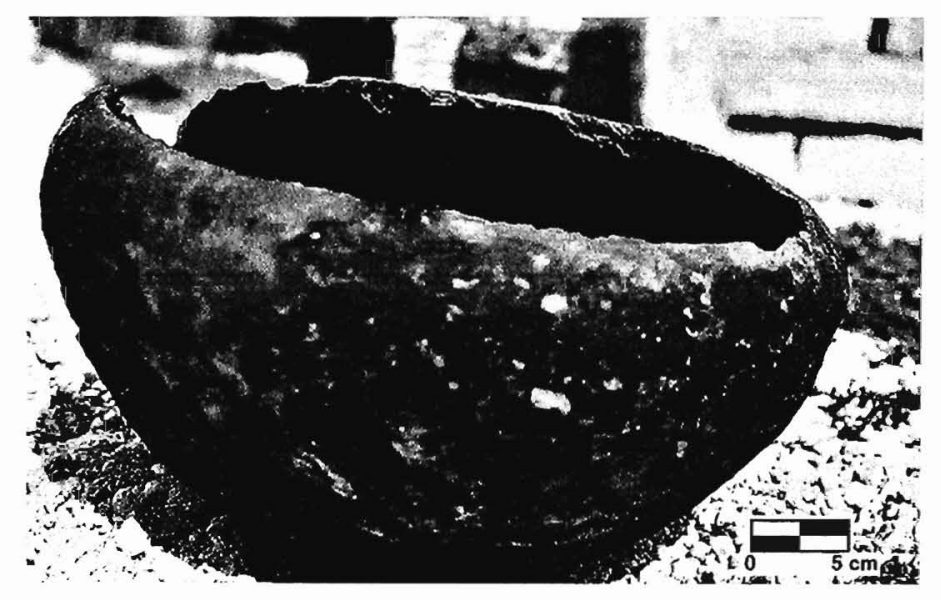

Fig. 4. Yapese Laminated pot photographed on Mogmog, Ulithi, in 1995 by the author. Note the laminated flakes peeling off the pot. 
The Yapese cooked in their pots by way of layering foodstuffs, adding water, and inserting a rolled-up banana leaf beneath the incurved rim to steam the food (Muiller 1917:68, 124). Pots were placed on a tripod of rocks (ngochol) over a small fire. After cooking, the pot was left upside down on the same ngochol. Yapese informants were not familiar with pottery uses outside cooking, but much earlier ethnographic texts detail other functions, such as containers for coconut meat (de Beauclair 1960:64), fires (de Beauclair 1960:64), infant burials (de Beauclair 1967), sacrificial offerings (de Beauclair 1966:201), and small objects (Müller 1917:124). ${ }^{4}$

Laminated ware exhibited more standardization than previous Yapese wares. Unlike the examples of dancing, tattooing, and woodcarving, ceramic pottery varied little in form. Intoh (1988:103) suggests the uniform firing conditions and the increasing number of oxidized sherd cores of this type as evidence for more controlled firing conditions. Dispersion measures (variance, standard deviation, and interquartile range) of rim thicknesses $(n=266)$ also indicate that Laminated ware was more uniform than previous Yapese wares. ${ }^{5}$ However, despite the absence of decoration and the appearance of uniformity, in the recent past, the Yapese esteemed some pots more than others. De Beauclair (1966:201) notes select villages also produced sacred pottery for sacrificial rituals at taliw (taboo) locations. I have not found physical differences in Yapese-produced ceramics excavated in sacred and nonsacred contexts.

Ceramic pot use played a role in social interactions among various groups and individuals. Ethnographic evidence details the complex and strict organization of food preparation and consumption in early twentieth-century Yap, where different pots were used for cooking the food of people of different social status and rank. A change of status for individuals brought along with it a new pot. When a girl reached womanhood, she would receive her own pot. When a high-caste girl first began to menstruate, she would be sent to a low-caste village for her period of seclusion. Her food would be cooked in a pot separate from her hosts. After marriage, a man also received a new pot or obtained one himself.

At the turn of the twentieth century, all households had at least two earthen pots, one for the male head of the household, and another for the mother and children (Christian 1967:292). The food of different household members was grown, cooked, and eaten in separate locations (Müller 1917:145). It was common for grandparents in a household to also have their own pots. In addition, specialists, and men of different "eating classes" (yogum), which was founded on "age, rank, and access to high-ranking food resources" (Lingenfelter 1975:95), required their food to be cooked in separate pots (Labby 1976:87-90; Lingenfelter 1975:95-98; Müller 1917:145, 246-248). In principle, high-caste villagers did not eat food cooked by low-caste peoples; older people strictly refrained from it, but high-caste youth could eat certain foods from low-caste land. I was told that if food were cooked inadvertently in the wrong pot, the pot would be discarded. In addition, pots never entered the house (de Beauclair 1966:203). Pots symbolized Yapese social identities not in their form, but in their ability to contain and separate the cooked food of individuals.

Laminated ware vessels were at the conjunction of ceramic pot production and metal pot replacement. Similar to other Oceanic peoples, the Yapese were more than passive recipients of superior technology from a dominant culture (see Tor- 
rence and Clarke 2000:12). The twentieth-century Yapese renown for cultural conservatism (e.g., Hanlon 1998:27; Hezel 1995:179; Schneider 1968:388; Yanaihara 1940:125; cf. Price 1975) did not prevent them from creatively incorporating new exotic material culture into earlier dynamic cultural paradigms. Archaeological investigations demonstrate that exotic artifacts are present in their archaeological landscape. Gifford and Gifford (1959:184) found occasional Chinese and Japanese sherds on the surface and upper levels of Yapese sites; I have found Asian sherds at a highly respected Gachpar site. ${ }^{6}$ From a strictly artifactual point of view, I find it questions the conservatism of the Yapese in the ethnographic present and the past given the need for the Yapese to negotiate the meaning and significance of these artifacts in their culture.

European and Western Carolinian encounters in the sixteenth century were accidental, involving trading and hostilities. Despite the European effort to avoid the Caroline Island area for fear of hitting low uncharted coral shoals (Burney 1967:3), non-Micronesian goods found their way into the complex interisland exchange systems long before colonization attempts. The Yapese probably became aware of metal pots at least in the sixteenth century due to sporadic Caroline voyages to the Philippines (Klein 1707) and European visits to Guam (Hezel 1979), which was part of the Yap-Caroline Islands' interaction sphere. In other words, the relatively late first firm report of a Dutch (Gheen Hugo Schapenham's Nassau Fleet) visit to Yap (1625) would not have prevented earlier European materials from reaching the Yapese (Lessa 1962:242). During later European expeditionary and warship visits in the Carolines, annual Carolinian flotillas voyaged to Guam to trade with the Spanish; trade items undoubtedly also reached the Yapese from annual Carolinian tribute voyages to Yap (von Chamisso 1986:284285).

It is unknown when the Yapese first became aware of metal pots, but they undoubtedly became readily available in the nineteenth century when European traders attempted to exploit the islands' resources. Initially, Yap was feared and avoided. English trader Andrew Cheyne comments on Yap's mid-nineteenth century reputation of killing ship crews "for the purpose of getting possession of what goods they had on board" (Shineberg 1971:247). ${ }^{7}$ While attempting to set up a bêche-de-mer (sea slug) operation in 1843, Cheyne notes that the Yapese have a society with people of varying distinctions and tasks and complex taboos concerning the sharing of food (Shineberg 1971 :250, 253). In 1865 before embarking for Yap, Alfred Tetens (1958:49) lists the trading materials stored in the inner cabins of the brig Vesta: "Among these articles were, especially, bright-colored cloth, pieces of iron, weapons, flint and steel, powder and shot, matches, Bohemian glass beads, iron cooking pots, and fishhooks." By 1880, the trading ventures of Alfred Tetens, David Dean O'Keefe, and others turned Yap into the commercial center of the Western Caroline Islands (Hezel 1983:281), thereby increasing the Yap Islanders' access to exotic goods.

Yap's colonial history began with Spanish control in 1885. The Spanish colonial regime (1885-1899) had little more than an evangelical agenda (Christmann et al. 1991), all the while Germany and Japan pursued their economic interests on Yap. Spanish governor José Montes de Oca (1893) of Yap noted nonlocal materials, such as bottles, casseroles, iron coffee pots, porcelain jars, and pots in 1893 . Unlike the Spanish, the ensuing German colonial administration (1899-1914) 
had strong economic interests. To accomplish their goals, the Germans introduced work projects (Hezel 1995:106), money, taxes, forced attendance at mission schools for children (Hezel 1995:81), the interdiction of intervillage warfare (Müller 1917:10), and a relaxation of the strict rules between castes (de Beauclair 1968:50). The heightened commercial activity increased Yapese access to nonlocal goods.

Japanese control of Yap (1914-1945) began after the outbreak of World War I. The Japanese colonial administration increased economic development with attempts to "modernize" Yap (e.g., Hezel 1995:169; Yanaihara 1940:304) and posed more restrictions than earlier colonial powers, such as the stopping of village exchanges (mitmit; Hezel 1995:179). Following the desire for exotic materials introduced by traders, colonial powers increased the importation of nonlocal trade goods, including pots and pans (Useem 1946:27) in the face of a decreasing Yapese population. With a quantitative increase in the barter for commodities after Yap became part of the Japanese South Seas mandate, Yanaihara (1940:149) records "the importation of chinaware and metal vessels has greatly reduced the native wooden ware and earthenware industries."

Following Japan's defeat in the Second World War, Yap became part of a United States Trust Territory of the Pacific Islands. Yap was administered first by the US Navy (1945-1951) and later by the Department of Interior (1951-1986) to foster the "political, economic, social and education advancement of the islands" (Hanlon 1998:52). The postwar years on Yap actually saw a drop in economic activity and the beginning of a traditionalist movement. This movement was initiated by the rebuilding of destroyed men's houses and the restoration of village exchanges (Hezel 1995:265, 277). Despite the fact that the low-caste continued to fulfill suon requests and that pots were once valued, the revitalization movement forwent clay pot production. The Yapese demand for clay pots had effectively ceased, replaced by affordable and more durable metal pots. ${ }^{8}$ Started in 1945, the United States Commercial Company's (later succeeded by the Island Trading Company) responsibility of developing Yap's economy, exposed the Yapese to the path of dependency where they bought commodities from trade stores and mail order catalogues. By the time the Department of Interior headed the trust territory in 1951, clay pot making was but a memory of the past. While the sale of handicrafts is presently part of Yap's tourist industry, despite attempts, clay objects are not part of the contemporary craft inventory.

\section{DISCUSSION}

Ceramic change and its demise are undoubtedly diverse in their causes and the result of multiple interacting factors (e.g., Kramer 1985; Le Moine 1987; Sargent and Friedel 1986; Stark 1991). New conditions encountered during contact and colonialism precipitated the Yapese to replace their ceramic vessel technology with metal pots. Particular contributing factors from an examination of the technological and social logic of the clay vessels include the form and function of clay pots in the society, the specialized labor required to produce ceramic containers, the durability offered by the replacement technology, the decrease in demand for pots caused by depopulation, and the blurring of eating customs between household members. 
Yapese pots were utilitarian cooking tools, esteemed for their durability and function. High- and low-caste Yapese informants gave only technical and performance reasons for the demise of the clay potting tradition, citing that metal pots were more durable and cooked food faster than their clay pots. Mundane clay pots were said to vary in size rather than form and to be heavier and more fragile than metal pots. Yapese informants told me one reason they continued to cook with their clay pots for as long as they did during German and Japanese colonial times is because people found food tasted better cooked in ceramic pots than in their metal counterparts. Despite a lacking social dimension in the responses to my questions about this technological replacement, I think a better understanding of this process can be reached by including the social logic, in which the technical factors are embedded (see J. Thomas 1996).

Yap's colonial past introduced sweeping new conditions in Yapese society. ${ }^{9}$ Engagements between the Yapese and their European and Japanese colonists involved entanglements where the "colonial process was influenced by the structures and events of early contact, just as these in turn were influenced by autonomous, precolonial cultural and social dynamics" (Thomas 1991:124). I suggest that the social and cooking functions of the vessels had more importance than inherent worth attributed to the pots. Besides cooking, the production and use of ceramic containers created and symbolized social distinctions within the household and between the genders and the castes in Yapese society. The lack of decoration or the undifferentiated nature of the pots did not diminish their role as important discriminators of identities.

During early contacts between the sixteenth and nineteenth centuries, the introduction of exotic materials became "entangled" in a prestige-goods economy (see N. Thomas 1996:89) with the Yapese imbuing value into rare metal goods, initially including metal pots. The accumulation, exchange, and presentation of exotic artifacts fed a prestige economy (e.g., in mitmit exchanges) that established and legitimated the role of individuals and villages in Yapese society. Prestigegoods became increasingly prominent as time went on in the dynamic and complex Yapese sociopolitical system, particularly after European engagements increased and subsequent colonial penetration beginning in the nineteenth century. Wilhelm Müller (1917:4, 377), a German ethnologist in the Südsee (South Seas) Expedition of 1909-1910, mentions that a few ornamented earthen plates from perhaps the first European settlement in Yap in the early nineteenth century were held in high esteem.

In the face of rapid depopulation and the increase of European domination and colonialism, the Yapese intensified their material discourse over power by accumulating Asian and European artifacts to maintain their threatened social and political system. The reliance on accumulating and exchanging new material culture for maintaining social distinctions endangered traditional knowledge held by specialists, for our purposes, pottery making. The added new labor demands of chiefs, who acted as intermediaries between Yapese workers (predominantly men) and German colonizers (Lingenfelter 1975:185), were also at the expense of earlier indigenous industries. I think colonial work projects left women, older individuals, and children to assume new responsibilities hitherto accomplished by men. Labor-intensive pot making skills suffered as low- and high-caste people chose to depend more on metal pots for their cooking needs. 
Unlike in other older Oceanic contexts, the demand for cooking containers never died out on Yap, but the lack of demand for clay pots threatened the survival of the caste- and gender-specific ceramic knowledge. Other indigenous societies who appropriated exotic metal pots continue to use both technologies, e.g., the Kalinga of the northern Philippines (Stark 1991), but the Yapese ceramic tradition became extinct with an assemblage replacement taking little more than 100 years. ${ }^{10}$ Yapese clay pot technology was not endangered until a lack of demand for clay pots resulting from severe Yapese depopulation and the accessibility of more durable metal containers increased. Fueled by epidemics started in the preceding nineteenth century, Yap's severe depopulation reduced the demand for clay pots. Inland areas, occupied predominantly with low-caste villages, were the first to be abandoned (Lingenfelter 1975:77).

Another factor behind the demise of ceramic vessels has to do with their inextricable links to low-caste production and Yapese social and political divisions. As demand for metal pots rose, ceramic production duties of the low-caste women fell. When technologically superior metal containers became more accessible, eventually saturating Yapese households, their once-held prestige value diminished. Metal containers performed the same cooking function as clay pots, but became embedded differently in Yapese society. Unlike earlier pots, metal pots were not tied to low-caste production and their role in differentiating the food of certain individuals or symbolizing rites of passage weakened. Eventually, metal pot use blurred the eating customs between household members, which at one time necessitated growing and cooking foods of particular members separately. The relaxing of food divisions on the members of the household (tabinaw), the most integral of units in the Yapese sociopolitical structure, gave more flexibility to Yapese customs, emanating from the household, e.g., exchange, interaction, and inheritance.

Japanese and later American colonial pressures contributed to the attenuation of eating restrictions in Yapese society. The Japanese and succeeding US Navy colonial governments discouraged the separate eating customs the Yapese practiced with clay and metal pots (Lingenfelter 1975:96-97, 187). The Yapese household endured an acute depopulation crisis, and men worked in off-island labor projects that could last many years during Japanese colonial rule. In 1934, American journalist Willard Price witnessed Yapese eating customs in the village of Fal, Rumung. Price (1936:39) notes "the girls were running frantically back and forth across the yard from pot to pot," and that "in the grounds of one dwelling as many as seven fireplaces, each covered by a thatch roof-seven kitchens to one house all tended by one woman!" Despite obstinate Yapese resistance to Japanese attempts to fortify Yap and increase its food production before and during the Second World War, Yapese adherence to traditional food production and consumption customs must have been difficult for them. Poyer $(1995: 240)$, however, notes that despite the major disruptions to daily life, food resources, political leadership, and community life during the Pacific War, the Yapese still practiced separate food preparation and eating customs. By the 1960s, less than 30 percent of Yapese households observed traditional cooking customs (Lingenfelter 1975:24). Though lacking in empirical data, I would estimate this decreasing trend in traditional cooking customs to have continued.

Functional considerations (see Bronitsky 1989) of the pots are also involved in 
the cessation of ceramic vessel production. The traditional heating process in Yapese cooking easily accommodated flat-bottomed metal pots. Similar to roundbottomed clay pots, metal pots were positioned on rock tripods over hearths invariably fueled by dried coconut husks. However, for stability issues, only flatbottomed pots could be used on gas (kerosene) stoves that were introduced during Trust Territory times. Without a hearth to maintain or thick soot build-up on the pots to clean, small transportable gas stoves simplified and shortened the cooking process. Flat-bottomed pottery with cornered walls could not be made without structurally compromising the textile strength of the laminated pots. As clay pots broke, more durable and longer-lasting metal pots generally replaced them. Before this, no cooking vessel or method was found superior to clay pot cooking on Yap, unlike the case in other Pacific Island societies where people adopted earth ovens for cooking food. The introduction of imported rice into the diet during Japanese colonialism may have also played a role in the demise of clay pottery. Unlike Yapese traditional foods, rice has a relatively shorter cooking time; Asian cuisine also tends to initially cook rice separately from other foods.

The fact that Yapese ceramic pots were not appreciated as art objects also aided their extinction. A similar trend may exist in Lapita pot assemblages that became less artistic and more utilitarian through time. This lack of artistic importance facilitated the replacement of pots in the Yapese scenario. The only technological developments witnessed in their 2000 years of manufacture were those that contributed to their strength and uniformity. There are no indications that clay vessels had aesthetic value or that the craft offered privilege to the potter, both of which may indicate that the ceramics were viewed as art forms and the ceramicist as an artist. Early Lapita ceramic pottery, on the other hand, is characterized as being highly decorative and in many cases functionally inadequate for mundane tasks (Ambrose 1997:531). Despite the loss of surface decoration on Lapita pots, Green (1979:14) argues for continuity of the decorative style by its application on other media, such as barkcloth and skin (tattoos). Later Lapita pottery, such as on Samoa, became plain, undecorated, and better suited for utilitarian tasks before disappearing altogether. What is important to note here is that as long as Yapese ceramic vessels had no aesthetic value, unlike art objects, there was no motivation to preserve them when new objects-metal pots-were able to better perform the functional uses of the ceramics. Similarly, certain prehistoric Oceanic ceramic pottery may have also lost esteem when no longer decorated, and therefore was more susceptible to extinction with the introduction of alternate cooking methods. Whether for cooking or artistic expression, the practice of specialized potting knowledge and skills declined and were not taught to the succeeding generations.

\section{CONCLUSIONS}

Pottery using societies around the world are rapidly disappearing. Studying this process contributes to the understanding of culture change today and in the past (Arnold 2000:118). Integrating different records and stressing the technological and social logic of cooking vessels, I suggest numerous interacting causes initiated during early cross-cultural engagements and intensified during colonialism led to the Yapese abandonment of ceramics. Factors contributing to the ease of replace- 
ment of ceramic pots in Yap include the form and function of clay vessels in the society, the specialized labor required to produce ceramic containers, and the durability offered by the replacement technology. Despite their technological advantages over their earlier clay counterparts, metal pots today have lost the ability to hold the complex Yapese identities and distinctions. The Yapese may have given up the strict food distinctions of varying household members that was once symbolized by clay pots, but the separation of different caste members' foods remains for the most part uncompromised.

This historical and particularistic Yapese case study supplies insights to our understanding of the dynamic factors involved in the process of ceramic loss on Oceanic islands in the past. As others have suggested, Lapita pots became functionally outmoded in the Pacific (e.g., Ambrose 1997:529; Green 1974). Given the embeddedness of pots in past and extant societies, the eventual demise of the potting tradition in prehistoric contexts affected social and political elements of these societies. Future Oceanic research into these elements in the records of the past (e.g., archaeology, ethnoarchaeology, and ethnohistory) will contribute to our understanding of the widespread ceramic cessation process. The long-lived Yapese ceramic tradition was gradually replaced; its traditions were profoundly affected by interactions with other peoples and their tools. The replacement of clay pots by metal ones symbolizes the weakening of past political prerogatives enjoyed by the high caste and the blurring of rank distinctions in the household. Outcomes of intersocietal interaction may also play a role in explaining the demise of ceramic pottery traditions in earlier Oceanic contexts. Whether or not a ceramic pot is a utilitarian tool or a complex symbol of artistic expression when its technology is dismissed by the producing culture, it is indicative of a changed perception of the object. It is a turning point in any society when long-held traditions disappear.

\section{ACKNOWLEDGMENTS}

I would like to thank the people of Yap and Ulithi for their hospitality and support throughout my research. Financial support was provided by the University of Oregon's Center for Asian and Pacific Studies, Graduate School, and Office of International Education and Exchange and the National Science Foundation (SBR9412851, SBR-9503035). This paper has benefited from comments by Greta Descantes, Rosalind Hunter-Anderson, Miriam Stark, and anonymous reviewers.

\section{NOTES}

1. The rise of laminated pottery correlates with shore and taro patch growth in Gachpar. A growing population intensifying taro cultivation along the coastal fringes of Yap would have required stronger, more durable pots than previously required to handle the longer cooking required to cook taro to the desired soft consistency. The Yapese consider taro a more dependable and productive food resource than yams. An increase in ceramic pots can result from orher factors, such as the need to keep the food of different household members separate. Coastal land additions of Gachpar include all of the land between the lagoon shore and the taro patches, approximately 11 ha; they allowed the wet taro patches to be enlarged and provided more living space for the growing population. The landscaping task involved infilling the lagoon shore, some of which was inhabited by mangrove colonies, with debris, coral heads, and sediments. Charcoal radiocarbon samples beneath architectural features and the absence of old Yapese ceramic type potsherds in the coastal area imply that habitation on the coastal land extensions began at the earliest after the introduction of Laminated pottery, at the end of the thirteenth century. 
2. All German references indicate the original German text page numbers.

3. While referring to the Yapese sociopolitical system as caste-based during the twentieth century does not correspond well to the inequalities inherent in the anthropological definition of caste (see Hunter-Anderson and Zan 1996; Petersen 1999), I have continued to apply low- and highcaste labels to prevent confusion with earlier ethnographic works (e.g., Lingenfelter 1975). Inaccurate as it might be, the term 'caste' is used by many Yapese, and has taken on a life of its own.

4. The people of Mogmog, Ulithi, atoll dwellers $170 \mathrm{~km}$ northeast from Yap, who relied on Yapese pots, relayed other uses for clay vessels to me in 1995. For example, a pot could be used for collecting the soot needed in tattooing. Soot was collected by scraping the interior surface of a pot that had lain overturned covering burning mahogany nuts.

5. Rim thickness is an average of three measurements.

6. Four small greenish brown glazed Asian sherds, one with a preformed beaded band segment decoration, were excavated from a site in Gachpar with much surface evidence of prestige goods. Carla Sinopoli of the University of Michigan Anthropology Museum identified the sherds as fragments of Southeast Asian stoneware jars, commonly referred to as "dragon jars." Comparisons of chemical characterization showed one of the sherds to clearly fit into Sinopoli's Group 2, the largest of four chemical compositional groups of dragon jars collected from the Philippines (Descantes et al. in press).

7. Other Yapese motivations also existed for attacking visiting ships. Based on Cheyne's edited reports, we know he unwittingly got involved in Yapese island power struggles (Hezel 1983:182). Cheyne also permitted one of his sick sailors to go on shore, and in effect, start an influenza epidemic that killed fifty Tomil District inhabitants in three days in 1843 (Shineberg $1971: 271$ ). In short, Cheyne's comment is an oversimplification of Yapese attacks on foreign ships; it nonetheless typifies the European sentiment of the day.

8. Interestingly, Ulithians claim the Yapese stopped supplying them clay pots before they stopped requesting them. Pot-cooking over a coconut husk hearth is still the most popular cooking method on many Outer Islands of Yap State, e.g., on Mogmog.

9. Much of my data gleaned from ethnographic texts originate from persons involved in their own country's colonial or neocolonial agendas (e.g., Müller 1917, 1918; Oca 1893; Schneider 1968; Senfft 1903).

10. This period is actually longer if we take into account that exotic materials, including pots, preceded European colonial attempts on Yap.

\section{REFERENCES CITED}

ALKIRE, W. H.

1989 [1965] Lamotrek Atoll: Inter-Island Socioeconomic Ties. 2nd ed. Prospect Heights, Illinois: Waveland Press.

Ambrose, W. R.

1997 Contradictions in Lapita pottery, a composite clone. Antiquity 71:535-538.

ARNOLD, P. J. III

2000 Working without a net: Recent trends in ceramic ethnoarchaeology. Journal of Archaeological Research 8(2): 105-133.

ATHens, J. S.

1995 Landscape Archaeology: Prehistoric Settlement, Subsistence, and Environment of Kosrae, Eastern Caroline Islands, Micronesia. Archaeological Data Recovery Investigations for the Kosrae Wastewater Project. Honolulu: International Archaeological Research Institute Inc.

Ayres, W. S.

1993 Nan Madol archaeological fieldwork: Final report. Manuscript on file. Eugene: University of Oregon.

Ayres, W. S., AND A. E. Haun

1990 Prehistoric food production in Micronesia, in Pacific Production Systems Approaches to Economic Prehistory: 210-227, ed. D. E. Yen and J. M. Mummery. Papers from a Symposium at the XV Pacific Science Congress, 1983. Canberra: Australian National University.

BRonitsky, G.

1989 Pottery Technology: Ideas and Approaches. Boulder, CO: Westview Press.

Burney, J.

1967 [1817] A Chronological History of the Voyages and Discoveries in the South Seas. Bibliotheca Australiana No. 7. Vol. 5. New York: Da Capo Press. 
Christian, F. W.

1967 [1899] The Caroline Islands: Travel in the Sea of the Little Lands. 2nd ed. London: Frank Cass \& Co. Ltd.

Christmann, H., P. Hempenstall, and D. A. Ballendorf

1991 Die Karolinen-Inseln in Deutscher Zeit: Eine kolonialgeschichtliche Fallstudie. Bremer AsienPazifik Studien, Bd. 1. Hamburg: Münster.

Clyde, P. H.

1935 Japan's Pacific Mandate. New York: The Macmillan Company.

DE Beauclair, I.

1960 Notes on pottery of Yap, Micronesia. Journal of East Asiatic Studies 9(2-3): 64-67.

1966 On pottery of Micronesia, Palauan lamps and Mediterranean lamps in the Far East. Bulletin of the Institute of Ethnology, Academia Sinica $21: 197-212$.

1967 Infant burial in earthenware pots and the pyramidal grave on Yap. Bulletin of the Institute of Ethnology, Academia Sinica $24: 35-40$.

1968 Social stratification in Micronesia: The low-caste people of Yap. Bulletin of the Institute of Eihnology, Academia Sinica 25:45-52.

Descantes, C.

1998 Integrating Archaeology and Ethnohistory: The Development of Exchange between Yap and Ulithi, Western Caroline Islands. Ph.D. diss., University of Oregon, Eugene. Ann Arbor: University Microfilms.

Descantes, C., H. NefF, and M. D. Glascock

in press Yapese Prestige Good: The INAA evidence, in Geochemical Evidence for Long Distance Exchange, vol. 3, ed. M. D. Glascock. Scientific Archaeology for the Third Millennium Series. Westport, CT: Greenwood Publishing Group Inc.

Descantes, C., H. Neff, M. D. Glascock, and W. R. Dickinson

2001 Chemical characterization of Micronesian ceramics through instrumental neutron activation analysis: A preliminary provenance study. Journal of Archaeological Science 28(11): 1185-1190

Dobres, M.-A., AND C. R. HoffMAN

1999 Introduction: A context for the present and future of technology studies, in The Social Dynamics of Technology: Practice, Politics, and World Vieus: 1-19, ed. M.-A. Dobres and C. R. Hoffman. Washington and London: Smithsonian Institution Press.

GifFord, E. W., AND D. S. Gifford

1959 Archaeological excavations in Yap. Anthropological Records 18(2):149-224. Berkeley and Los Angeles: University of California Press.

Graves, M. W., T. L. Hunt, And D. Moore

1990 Ceramic production in the Mariana Islands: Explaining change and diversity in prehistoric interaction and exchange. Asian Perspectives 29:211-233.

Green, R. C.

1974 Report 40: A review of portable artefacts from Western Samoa, in Archaeology in Western Samoa: 2:245-275, ed. R. C. Green and J. M. Davidson. Bulletin of the Auckland Institute and Museum 7. Auckland: Auckland Institute and Museum.

1979 Early Lapita art from Polynesia and Island Melanesia: Continuities in ceramic, barkcloth, and tattoo decorations, in Exploring the Visual Art of Oceania: Australia, Melanesia, Micronesia, and Polynesia: 13-31, ed. S. M. Mead. Honolulu: University of Hawai'i Press.

HANLON, D.

1998 Remaking Micronesia: Discourses over Development in a Pacific Territory, 1944-1982. Honolulu: University of Hawai'i Press.

HEZEL, F. X.

1979 Foreign Ships in Micronesia: A Compendium of Ship Contacts with the Caroline and Marshall Islands, 1521-1885. Saipan: Trust Territory Printing Office.

1983 The First Taint of Civilization: A History of the Caroline and Marshall Islands in Pre-Colonial Days, 1521-1885. Pacific Islands Monograph Series 1. Honolulu: University of Hawai'i Press.

1995 Strangers in Their Own Land: A Century of Colonial Rule in the Caroline and Marshall Islands. Pacific Islands Monograph Series 13. Honolulu: University of Hawai'i Press.

HUNTER-ANDERSON, R. L.

1983 Yapese Settlement Patterns: An Ethnoarchaeological Approach. Agana, Guam: Pacific Studies Institute. 
Hunter-ANDERSON, R. L., AND Y. ZAN

1996 Demystifying the Sawei, a traditional interisland exchange system. ISLA: A Journal of Micronesian Studies 4(1): 1-45.

INTOH, M

1988 Changing Prehistoric Yapese Pottery Technology: A Case Study of Adaptive Transformation. Ph.D. diss., University of Otago, Dunedin.

1990 Ceramic environment and technology: A case study in the Yap Islands in Micronesia. Man and Culture in Oceania $6: 35-52$.

INTOH, M., AND F. LEACH

1985 Archaeological Investigations in the Yap Islands, Micronesia: First Millennium B.C. to the Present Day. BAR International Series 277. Oxford: British Archaeological Reports.

KLEIN, P.

1707 Lettre écrite de Manille le 10. de Juin 1697. Par le Père Paul Clain de la Compagnie de Jésus, au Révérend Père Thyrse Gonzalez, Général de la même Compagnie, sur la nouvelle découverte qu'on a faite de trende-deux îles au Sud des Îles Marianes, in Lettres édifantes et curieuses, écrites des missions étrangères par quelques missionaires de la Compagnie de Jésus $1: 112-136$.

Kramer, C.

1985 Ceramic ethnoarchaeology. Annual Review of Anthropology $14: 77-102$.

LABBX, D.

1976 The Demystification of Yap: Dialectics of Culture on a Micronesian Island. Chicago: University of Chicago Press.

LEACH, H. M.

1982 Cooking without pots: Aspects of prehistoric and traditional Polynesian cooking. New Zealand Journal of Archaeology $4: 149-156$.

Lighrfoor, K. G.

1995 Culture contact studies: Redefining the relationship between prehistoric and historical archaeology. American Antiquity 60(2): 199-217.

Le Morne, G.

1987 The loss of pottery in Polynesia. New Zealand Journal of Archaeology 9:25-32.

LESSA, W. A.

1962 An evaluation of early descriptions of Carolinian culture. Ethnohistory 9(4):313-403.

LINGENFELTER, S. G.

1975 Yap, Political Leadership and Culture Change in an Island Society. Honolulu: University of Hawai'i Press.

MÜller (WISMAR), W.

1917 Yap, in Ergebnisse der Südsee Expedition 1908-1910, ed. Georg Thilenius, 1917-1918. II: Ethnographie, B: Mikronesien. Band 2, Halband 1. Hamburg: L. Friederichsen \& Co. Human Relations Area Files unedited translated manuscript.

1918 Yap, in Ergebnisse der Südsee Expedition 1908-1910, ed. Georg Thilenius, 1917-1918. Band 2, Halband 2. Hamburg: L. Friederichsen \& Co.

OCA, J. M. DE

1893 Carolinas occidentales: La isla de Yap. Boletín de la Sociedad Geografica de Madrid 24:251279.

Petersen, G.

1999 Sociopolitical rank and conical clanship in the Caroline Islands. Journal of the Polynesian Society $108(4): 367-410$.

POYER, L.

1995 Yapese experiences of the Pacific war. ISLA: A Journal of Micronesian Studies 3(2):223255.

PRICE, S. T.

1975 The Transformation of Yap: Causes and Consequences of Socio-Economic Change in Micronesia. Ph.D. diss., Washington State University, Pullman.

PRICE, W.

1936 Pacific Adventure. New York: Reynal \& Hitchcock. 


\section{RAINBIRD, P.}

1999 Entangled biographies: Western Pacific ceramics and the tombs of Pohnpei. World Archaeology 31(3):214-224.

Sargent, C. F., and D. A. Friedel

1986 From clay to metal: Culture change and container usage among the Bariba of northern Bénin, West Africa. The African Archaeological Review $4: 177-195$.

SCHNEIDER, D. M.

1968 Abortion and depopulation on a Pacific island, in Peoples and Cultures of the Pacific: 383406, ed. A. P. Vayda. Garden City, NY: The Natural History Press.

SENFFT, A.

1903 Ethnographische Beiträge über die Karolineninsel Yap. Petermanns Mitteilungen 49:49-60, 83-87. Human Relations Area Files unedited translated manuscript.

SHINEBERG, D. (ED.)

1971 The Trading Voyages of Andrew Cheyne 1841-1844. Canberra: Australia National University Press.

Shutler, R. JR., Y. H. Sinoto, and J. Takayama

1984 Report 1: Preliminary Excavations of Fefan Island Sites, Truk Islands, in Caroline Islands Archaeology: Investigations on Fefan, Faraulep, Woleai, and Lamotrek: 1-64, ed. Yosihiko H. Sinoto. Pacific Anthropological Records 35. Honolulu: Department of Anthropology. Bernice P. Bishop Museum.

STARK, M. T.

1991 Ceramic change in ethnoarchaeological perspective: A Kalinga case study. Asian Perspectives $30(2): 193-216$.

Tetens, A.

1958 [1888] Among the Savages of the South Seas: Memoirs of Micronesia, 1862-1868. Translated by Florence Spoehr. Stanford: Stanford University Press.

ThOMAS, J.

1996 Time, Culture and Identity: An Interpretative Archaeology. London and New York: Routledge.

Thomas, $\mathrm{N}$.

1991 Entangled Objects: Exchange, Material Culture, and Colonialism in the Pacific. Cambridge and London: Harvard University Press.

1996 Out of Time: History and Evolution in Anthropological Discourse. 2nd ed. Ann Arbor: University of Michigan Press.

1997 In Oceania: Visions, Artifacts, Histories. Durham and London: Duke University Press.

Torrence, R., AND A. Clarke

2000 Negotiating difference: Practice makes theory for contemporary archaeology in Oceania, in The Archaeology of Difference: Negotiating Cross-Cultural Engagements in Oceania: 1-31, ed. R. Torrence and A. Clarke. London and New York: Routledge.

USEEM, J.

1946 Notes on Yap (and Ulithi). Unpublished manuscript. Honolulu: University of Hawai" $i$ Library.

von Chamisso, A.

1986 [1835] A Voyage Around the World with the Romanzov Exploring Expedition in the Years 1815-1818 in the Brig Rurik, Captain Otto von Kotzebue, ed. and trans. Henry Kratz. Honolulu: University of Hawai'i Press.

YANAIHARA, T.

1940 [1937] Pacific Islands under Japanese Mandate. London and New York: Oxford University Press.

\section{ABSTRACT}

The loss of ceramic technology is widespread in Oceanic island societies. While this disappearance has taken place at different times, under different conditions, on different Pacific Islands, a model created by examining the technology loss of one so- 
ciety may cast light on the contributing factors to the decline of ceramic production of other Oceanic contexts. A model to account for the relatively recent end of ceramic pot production and use on the island of Yap, Federated States of Micronesia, during the colonial period is offered. Ceramic manufacture on Yap was at least a 2000-year-old tradition before it ceased in the twentieth century. Relying on a historical approach that considers the social dynamics of pots and a combination of archaeological, ethnographic, and ethnohistoric records, the Yapese gradually replaced their ceramic vessel technology with metal pots because of new conditions encountered during contact and colonialism. Factors involved in the ease of replacement of ceramic pots include limited access to the specialized labor required to produce ceramic containers, the superior durability offered by the replacement technology, and the fact that ceramic pots were valued more for their function. KeYwords: Yap, pottery, ceramic change, colonialism. 